\title{
Population of Aphanizomenon from the Gulf of Gdańsk (Southern Baltic Sea): differences in phenotypic and genotypic characteristics
}

\author{
Katarzyna A. Palińska · Waldemar Surosz
}

Published online: 29 May 2008

(C) Springer Science+Business Media B.V. 2008

\section{Erratum to: Hydrobiologia \\ DOI 10.1007/s10750-008-9388-y}

Table 3: in the title of the table, 'GeneBank' should read 'GenBank'. The footnote under the table should not appear. doi:10.1007/s10750-008-9388-y.

K. A. Palińska

Geomicrobiology ICBM, Carl von Ossietzky University of Oldenburg, PO Box 2503, 26111 Oldenburg, Germany

W. Surosz $(\bowtie)$

Institute of Oceanography, University of Gdańsk,

Al. Piłsudskiego 46, 81-378 Gdynia, Poland

e-mail: ocews@univ.gda.pl 